\title{
Community mothers' programme: randomised controlled trial of non-professional intervention in parenting
}

\author{
Z Johnson, F Howell, B Molloy
}

\begin{abstract}
Objective-To see whether non-professional volunteer community mothers could deliver a child development programme to disadvantaged first time mothers for children aged up to 1 year.

Design-Randomised controlled trial.

Setting-A regional health authority in Dublin.

Subjects-262 first time mothers who were delivered during six months in 1989 and who lived in a deprived area of Dublin; 30 experienced mothers from the same community recruited as community mothers.
\end{abstract}

Interventions-All the first time mothers received standard support from the public health nurse. In addition, those in the intervention group received the services of a community mother, who was scheduled to visit monthly during the first year of the child's life.

Results-232 (89\%) first time mothers completed the study -127 in the intervention group, 105 controls. At the end of the study children in the intervention group were more likely to have received all of their primary immunisations, to be read to, and to be read to daily, played more cognitive games; and were exposed to more nursery rhymes. They were less likely to begin cows' milk before 26 weeks and to receive an inappropriate energy intake and inappropriate amounts of animal protein, non-animal protein, wholefoods, vegetables, fruit, and milk. Mothers in the intervention group also had a better diet than controls. At the end of the study they were less likely to be tired, feel miserable, and want to stay indoors; had more positive feelings; and were less likely to display negative feelings.

Conclusion-Non-professionals can deliver a health promotion programme on child development effectively. Whether they can do so as effectively as professionals requires further study.

\section{Introduction}

The quality of parenting is important in early development. The Early Childhood Development Unit in the University of Bristol has therefore developed a child development programme, in which health visitors give parents of young children support and guidance on health and development matters. ${ }^{1}$ Parents are regarded as the experts on their own child and are encouraged to solve their own problems in child rearing. Five health authorities in England and Wales and one in Ireland have had encouraging results with this programme. ${ }^{2}$ In Ireland, however, lack of resources meant that the programme could not continue. It was therefore decided to recruit nonprofessionals in the form of successful experienced mothers to implement the programme instead of health professionals. Accordingly, a community mothers' programme was launched in Dublin in 1983.
The community mothers' programme aims at using experienced volunteer mothers in disadvantaged areas to give support and encouragement to first time parents in rearing their children using the child development programme. Potential community mothers are identified by the local public health nurse and interviewed by a regional family development nurse to assess suitability. Community leaders and self promoting individuals are generally not regarded as suitable. Once accepted, the community mother undergoes four weeks of training, during which the concepts of the programme are explained. She also meets other community mothers, and they exchange ideas and explore ways of delivering the programme. After training, each community mother works under the guidance of a family development nurse, who serves as a resource person, confidante, and monitor. Each community mother aims at supporting five to 15 first time parents. By the end of 1988, 90 community mothers had been recruited and there were 450 families in the programme. The community mothers' programme was evaluated to see if non-professionals could deliver the child development programme effectively. We present the principal findings.

\section{Subjects and methods}

All first time mothers who delivered over six months in 1989 and lived in a defined deprived area were randomly assigned to receive the programme or serve as a control. Randomisation was achieved by preparing 280 cards from a table of random numbers assigning families to the intervention group (odd numbers) or the control group (even numbers). The cards were sealed in consecutively marked envelopes, which were drawn in order as required. The family development nurse reviewed each birth in her region and identified mothers who were eligible for inclusion. The next envelope was opened and she then visited the new parent, explained the programme, and either offered the help of a community mother or asked if the parent would serve as a control. The community mother was scheduled to visit once a month for the first year of the child's life. Both groups also received the standard support from their own local public health nurse, which consisted of visits at birth and six weeks and at other times as required. Both groups received invitations to attend for primary immunisations and a development assessment. Baseline demographic data were collected at first interview and an evaluation questionnaire administered on the child's first birthday. All data were collected by the family development nurse.

\section{QUESTIONNAIRE EVALUATION}

As the community mothers' programme was similar to the child development programme we used a similar questionnaire. ${ }^{2}$ Data were collected on demography, 
environmental factors, mother's self esteem, immunisations and hospitalisations, child and mother's nutrition, and developmental stimulation factors. Four aspects of mother's self esteem were measured by asking about tiredness, headaches, feeling miserable, and a desire to stay indoors. Nutrition was assessed by 24 hour recall. Advice from dietitians allowed the responses to be categorised as appropriate or inappropriate. ${ }^{3}$ Inappropriate intake refers to not enough or too much of a particular food.

Three modules in the community mothers' programme were implemented with the aid of cartoon sequences previously used for the child development programme: educational development, including early reading to the child; language development, using nursery rhymes as a stimulus; and cognitive development, through play. Mothers were asked how often they read to their child, what type of games they played with them, and the extent to which they used song or nursery rhymes. The question on games was open and

TABLE I-Sociodemographic profile of 232 participants. Except where stated otherwise figures are numbers (percentages) of subjects

\begin{tabular}{|c|c|c|c|c|}
\hline Variable & Category & $\begin{array}{l}\text { Intervention } \\
\text { group } \\
(n=127)\end{array}$ & $\begin{array}{l}\text { Control } \\
\text { group } \\
(n=105)\end{array}$ & $\mathrm{p}$ Value \\
\hline Sex of infant & $\left\{\begin{array}{l}\text { Male } \\
\text { Female }\end{array}\right.$ & $\begin{array}{l}62(49) \\
65(51)\end{array}$ & $\left.\begin{array}{l}51(49) \\
54(51)\end{array}\right\}$ & NS \\
\hline $\begin{array}{l}\text { Mothers' age } \\
\text { (years) }\end{array}$ & $\left\{\begin{array}{l}\operatorname{Mean}(\mathrm{SD}) \\
\text { Left school (SD) }\end{array}\right.$ & $\begin{array}{l}24 \cdot 1(4 \cdot 4) \\
15 \cdot 9(1 \cdot 4)\end{array}$ & $\left.\begin{array}{l}23.1(3.7) \\
15.7(1.7)\end{array}\right\}$ & NS \\
\hline $\begin{array}{l}\text { Mothers' marital } \\
\text { status }\end{array}$ & $\left\{\begin{array}{l}\text { Single } \\
\text { Married } \\
\text { Separated }\end{array}\right.$ & $\begin{array}{l}65(51) \\
61(48) \\
1(1)\end{array}$ & $\left.\begin{array}{c}64(61) \\
40(38) \\
1(1)\end{array}\right\}$ & NS \\
\hline $\begin{array}{l}\text { Mothers' } \\
\text { employment } \\
\text { status }\end{array}$ & $\left\{\begin{array}{l}\text { Employed } \\
\text { Unemployed }\end{array}\right.$ & $\begin{array}{l}37(29) \\
90(71)\end{array}$ & $\left.\begin{array}{l}18(17) \\
87(83)\end{array}\right\}$ & $<0.05$ \\
\hline $\begin{array}{l}\text { Fathers' } \\
\text { employment } \\
\text { status }\end{array}$ & $\left\{\begin{array}{l}\text { Employed } \\
\text { Unemployed } \\
\text { Unknown }\end{array}\right.$ & $\begin{array}{l}65(51) \\
34(27) \\
28(22)\end{array}$ & 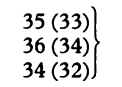 & $<0.05$ \\
\hline Social class ${ }^{\star}$ & $\left\{\begin{array}{l}\text { I, II, IIINM } \\
\text { IIIM, IV, V } \\
\text { Unknown }\end{array}\right.$ & $\begin{array}{c}16(13 \\
110(87) \\
1(1)\end{array}$ & $\left.\begin{array}{c}8(8) \\
93(89) \\
4(4)\end{array}\right\}$ & NS \\
\hline Housing & $\left\{\begin{array}{l}\text { Private } \\
\text { Local authority }\end{array}\right.$ & $\begin{array}{l}56(44) \\
71(56)\end{array}$ & $\left.\begin{array}{l}38(36) \\
67(64)\end{array}\right\}$ & NS \\
\hline
\end{tabular}

${ }^{\star}$ Registrar general's classification of occupations. NM=Non-manual. M=Manual.

TABLE II-Mothers' self esteem on child's first birthday. Results expressed as numbers (percentages) of subjects

\begin{tabular}{|c|c|c|c|c|c|}
\hline Variable & Group & Yes & No & $\mathrm{p}$ Value & $\begin{array}{c}\text { Relative risk } \\
\text { (95\% confidence } \\
\text { interval) }\end{array}$ \\
\hline Tired & $\left\{\begin{array}{l}\text { Intervention }(n=127) \\
\text { Control }(n=105)\end{array}\right.$ & $\begin{array}{l}99(78) \\
95(90)\end{array}$ & $\left.\begin{array}{l}28(22) \\
10(10)\end{array}\right\}$ & $<0.01$ & $0.86(0.77$ to 0.97$)$ \\
\hline Headaches & $\left\{\begin{array}{l}\text { Intervention }(n=127) \\
\text { Control }(n=105)\end{array}\right.$ & $\begin{array}{l}62(49) \\
52(50)\end{array}$ & $\left.\begin{array}{l}65(51) \\
53(50)\end{array}\right\}$ & 0.92 & $0.99(0.76$ to 1.28$)$ \\
\hline Miserable & $\left\{\begin{array}{l}\text { Intervention }(n=127) \\
\text { Control }(n=105)\end{array}\right.$ & $\begin{array}{l}73(57) \\
80(76)\end{array}$ & $\left.\begin{array}{l}54(43) \\
25(24)\end{array}\right\}$ & $<0.003$ & $0.75(0.63$ to 0.90$)$ \\
\hline Staying in & $\left\{\begin{array}{l}\text { Intervention }(\mathrm{n}=127) \\
\text { Control }(\mathrm{n}=105)\end{array}\right.$ & $\begin{array}{l}40(31) \\
57(54)\end{array}$ & $\left.\begin{array}{l}87(69) \\
48(46)\end{array}\right\}$ & $<0.001$ & $0.58(0.43$ to 0.79$)$ \\
\hline
\end{tabular}

TABLE III-Numbers of infants admitted to hospital

\begin{tabular}{lcc}
\hline & $\begin{array}{c}\text { Inter- } \\
\text { vention } \\
\text { group }\end{array}$ & $\begin{array}{c}\text { Control } \\
\text { group }\end{array}$ \\
\hline Chest infection & 7 & 5 \\
Gastroenteritis & 5 & 4 \\
Tonsillitis & 2 & 2 \\
Meningitis & 1 & 0 \\
Pertussis & 0 & 1 \\
Other infections & 4 & 5 \\
Feeding problems & 2 & 2 \\
Prematurity & 1 & 0 \\
Near miss/cot & 1 & 0 \\
death & 1 & 0 \\
Hernia repair & 0 & 1 \\
Scalds & 0 & 1 \\
Tablet ingestion & 0 & 21 \\
\hline Total & 24 & 21 \\
\hline
\end{tabular}

each game mentioned was recorded. Games were divided into "cognitive" and "motor." Cognitive games included hide and seek, singing games, and number games. Motor games included boxing or playing with a ball. Each game was given a score of one, and these were then totalled. The frequency with which mothers would sing or say nursery rhymes to their child was measured on a $10 \mathrm{~cm}$ analogue scale used in evaluating the child development programme. ${ }^{2}$

Lastly, mothers were asked about their feelings during the year since their child was born. We thought this might give some measure of morale at the end of the first year. Replies were noted as "positive" or "negative." A positive feeling might be "I enjoyed every day, and watching the baby come along was a great experience." A negative feeling might be "Terrible! I found it very hard to cope." Each positive feeling was given a score of one, as was each negative feeling. Scores were totalled separately, so that total positive and total negative scores were derived for each mother.

\section{STATISTICAL METHODS}

Statistical analysis was done by using the SAS system, version 6.06 (SAS Institute, Cary, North Carolina). The $\chi^{2}$ test was used for comparison of proportions. Relative risks and $95 \%$ confidence intervals were calculated. To control for the possible confounding effects of employment the MantelHaenszel method was used. For continuous variables Student's $t$ test for unpaired data was used, and Tukey's studentised range test was used to calculate $95 \%$ confidence intervals for the mean difference between the intervention group and controls. The possible confounding effects of employment were investigated by two way analysis of variance with the generalised linear modelling method. Means are expressed with one standard deviation (SD).

\section{Results}

Two hundred and sixty two mother and infant pairs were randomly allocated to the intervention group $(n=141)$ or control group $(n=121)$. They were visited by the family development nurse and invited to participate. All agreed. At evaluation on the child's first birthday $232(89 \%)$ pairs had completed the study (127 in the intervention group, 105 controls). Of the remaining 30, 15 (six in the intervention group, nine controls) had moved away; 10 (six, four) had dropped out; three children (all controls) were taken into protective custody because of child abuse; one mother in the intervention group had died; and one child in the intervention group had spent practically the whole year in hospital attached to an apnoea alarm.

The sociodemographic characteristics of the 232 mother and infant pairs who completed the study are shown in table I. There were no significant differences between the groups except for employment status of mothers and fathers. Of the 127 mothers in the intervention group, $82(65 \%)$ received at least 10 visits from their community mother, $34(27 \%)$ received between five and nine visits, and $11(9 \%)$ received fewer than five visits.

Table II outlines the differences in the two groups as regards mothers' self esteem at the end of the study. Women in the intervention group did significantly better in all aspects of self esteem except headaches, which showed no difference in prevalence between the groups.

One hundred and seventy six (76\%) children received all three shots of their primary immunisations by their first birthday. Those in the intervention group (108; 85\%) performed significantly better than the controls $(68 ; 65 \%)(p<0.001$; relative risk $1.31,95 \%$ confidence interval $1 \cdot 12$ to $1 \cdot 54)$. Of those who received at least one shot of their primary immunisation schedule, $169(75 \%)$ received diphtheria-tetanuspertussis vaccine. There was no significant difference between the intervention group $(98 ; 77 \%)$ and the controls $(71 ; 68 \%)$ in receipt of diphtheria-tetanuspertussis vaccine.

Forty five children were admitted to hospital during the study, $24(19 \%)$ from the intervention group and 21 $(20 \%)$ controls $(p=N S)$. Those from the intervention group spent 336 days in hospital and those from the control group 136 days. There was no significant difference between the groups in mean number of days spent in hospital (intervention group 2.6 days, control group 1.3 days; $p=0.88$ ). Among children admitted, however, those from the intervention group had a longer mean stay (14.0 days) than the controls 
TABLE IV-Twenty four hour dietary recall history for children at evaluation. Results expressed as numbers (percentages) of subjects

\begin{tabular}{|c|c|c|c|c|c|}
\hline Food item & Group & Inappropriate & Appropriate & $\mathrm{p}$ Value & $\begin{array}{c}\text { Relative risk } \\
\text { (95\% confidence } \\
\text { interval) }\end{array}$ \\
\hline Animal protein & $\left\{\begin{array}{l}\text { Intervention }(n=127) \\
\text { Control }(n=105)\end{array}\right.$ & $\begin{array}{l}22(17) \\
61(58)\end{array}$ & $\left.\begin{array}{c}105(83) \\
44(42)\end{array}\right\}$ & $<0.001$ & $0.30(0.21$ to 0.43$)$ \\
\hline Non-animal protein & $\begin{array}{l}\left\{\begin{array}{l}\text { Intervention }(n=127) \\
\text { Control }(n=105)\end{array}\right. \\
\left\{\begin{array}{l}\text { Intervention }(n=127)\end{array}\right.\end{array}$ & $\begin{array}{l}20(16) \\
51(49) \\
18(14)\end{array}$ & $\left.\begin{array}{r}107(84) \\
54(51) \\
109(86)\end{array}\right\}$ & $\begin{array}{l}<0.001 \\
<0.001\end{array}$ & $0.32(0.22$ to 0.49$)$ \\
\hline Wholefoods & Control $(n=105)$ & $57(54)$ & $48(46)\}$ & $<0.001$ & $0.26(0.17$ to 0.39$)$ \\
\hline Vegetables & $\left\{\begin{array}{l}\text { Intervention }(0 \cdot 127) \\
\text { Control }(n=105)\end{array}\right.$ & $\begin{array}{l}15(12) \\
40(38)\end{array}$ & $\left.\begin{array}{r}112(88) \\
65(62)\end{array}\right\}$ & $<0.001$ & $0.31(0.19$ to 0.51$)$ \\
\hline Fruit & $\left\{\begin{array}{l}\text { Intervention }(\mathrm{n}=127) \\
\text { Control }(105)\end{array}\right.$ & $\begin{array}{l}29(23) \\
.64(61)\end{array}$ & $\left.\begin{array}{l}98(77) \\
41(39)\end{array}\right\}$ & $<0.001$ & $0.38(0.27$ to 0.52$)$ \\
\hline Milk & $\left\{\begin{array}{l}\text { Intervention }(n=127) \\
\text { Control }(n=105)\end{array}\right.$ & $\begin{array}{c}8(6) \\
29(28)\end{array}$ & $\left.\begin{array}{r}119(94) \\
76(72)\end{array}\right\}$ & $<0.001$ & $0.23(0.12$ to 0.44$)$ \\
\hline Energy intake & $\left\{\begin{array}{l}\text { Intervention }(n=127) \\
\text { Control }(n=105)\end{array}\right.$ & $\begin{array}{c}9(7) \\
46(44)\end{array}$ & $\left.\begin{array}{c}118(93) \\
59(56)\end{array}\right\}$ & $<0.001$ & $0.16(0.09$ to 0.27$)$ \\
\hline
\end{tabular}

TABLE $\mathrm{v}-T$ Twenty four hour dietary recall history for mothers at evaluation. Results expressed as numbers (percentages) of subjects

\begin{tabular}{|c|c|c|c|c|c|}
\hline Food item & Group & Inappropriate & Appropriate & p Value & $\begin{array}{c}\text { Relative risk } \\
\text { (95\% confidence } \\
\text { interval) }\end{array}$ \\
\hline Animal protein & $\left\{\begin{array}{l}\text { Intervention }(n=127) \\
\text { Control }(n=105)\end{array}\right.$ & $\begin{array}{l}31(24) \\
55(52)\end{array}$ & $\left.\begin{array}{l}96(76) \\
50(48)\end{array}\right\}$ & $<0.01$ & $0.47(0.33$ to 0.66$)$ \\
\hline Non-animal protein & $\begin{array}{l}\left\{\begin{array}{l}\text { Intervention }(n=127) \\
\text { Control }(n=105)\end{array}\right. \\
\left\{\begin{array}{l}\text { Intervention }(n=127)\end{array}\right.\end{array}$ & $\begin{array}{l}54(43) \\
76(72) \\
43(34)\end{array}$ & $\left.\begin{array}{l}73(57) \\
29(28) \\
84(66)\}\end{array}\right\}$ & $\begin{array}{l}<0.01 \\
<0.01\end{array}$ & $\begin{array}{l}0.59(0.47 \text { to } 0.74) \\
0.44(0.34 \text { to } 0.56)\end{array}$ \\
\hline Wholefoods & Control $(n=105)$ & $81(77)$ & $24(23)\}$ & $<0.01$ & $0.44(0.34$ to 0.56$)$ \\
\hline Vegetables & $\left\{\begin{array}{l}\text { Intervention }(0 \cdot 127) \\
\text { Control }(n=105)\end{array}\right.$ & $\begin{array}{l}46(36) \\
62(59)\end{array}$ & $\left.\begin{array}{l}81(64) \\
43(41)\end{array}\right\}$ & $<0.01$ & $0.61(0.47$ to 0.81$)$ \\
\hline Fruit & $\left\{\begin{array}{l}\text { Intervention }(n=127) \\
\text { Control }(n=105)\end{array}\right.$ & $\begin{array}{l}72(57) \\
77(73)\end{array}$ & $\left.\begin{array}{l}55(43) \\
28(27)\end{array}\right\}$ & $<0.01$ & $0.77(0.67$ to 0.94$)$ \\
\hline Milk & $\left\{\begin{array}{l}\text { Intervention }(n=127) \\
\text { Control }(n=105)\end{array}\right.$ & $\begin{array}{l}56(44) \\
72(69)\end{array}$ & $\left.\begin{array}{c}71(56) \\
33(31)\end{array}\right\}$ & $<0.01$ & $0.64(0.51$ to 0.81$)$ \\
\hline Energy intake & $\left\{\begin{array}{l}\text { Intervention }(n=127) \\
\text { Control }(n=105)\end{array}\right.$ & $\begin{array}{l}33(26) \\
52(49)\end{array}$ & $\left.\begin{array}{l}94(74) \\
53(51)\end{array}\right\}$ & $<0.01$ & $0.53(0.37$ to 0.74$)$ \\
\hline
\end{tabular}

TABLE VI-Developmental and positive/negative scores

\begin{tabular}{lllll}
\hline Variable & Group & Mean (SD) & $\begin{array}{c}\text { Difference } \\
\text { between } \\
\text { means }\end{array}$ & $\begin{array}{c}95 \% \text { Confidence } \\
\text { interval }\end{array}$ \\
\hline Cognitive games & $\begin{array}{l}\text { Intervention } \\
\text { Control }\end{array}$ & $\left.\begin{array}{l}3.75(2.11) \\
1.62(1.39)\end{array}\right\}$ & 2.13 & 1.65 to 2.60 \\
Motor games & $\begin{array}{l}\text { Intervention } \\
\text { Control }\end{array}$ & $\left.\begin{array}{l}0.83(0.76) \\
0.76(0.84)\end{array}\right\}$ & 0.07 & -0.13 to 0.28 \\
Nursery rhymes & $\left\{\begin{array}{l}\text { Intervention } \\
\text { Control }\end{array}\right.$ & $\left.\begin{array}{l}7.74(1.65) \\
3.50(3.24)\end{array}\right\}$ & 4.24 & 3.59 to 4.88 \\
Positive feelings & $\left\{\begin{array}{l}\text { Intervention } \\
\text { Control }\end{array}\right.$ & $\left.\begin{array}{l}2.61(1.28) \\
1.17(1.01)\end{array}\right\}$ & 1.44 & 1.14 to 1.75 \\
Negative feelings & $\left\{\begin{array}{l}\text { Intervention } \\
\text { Control }\end{array}\right.$ & $\left.\begin{array}{l}0.93(0.87) \\
1.42(1.25)\end{array}\right\}$ & -0.50 & -0.77 to -0.23 \\
\hline
\end{tabular}

(7.0 days) $(p<0 \cdot 05)$. Reasons for hospitalisation are listed in table III. Eleven children suffered an accident during the period, three in the intervention group and eight controls (NS). Of the accidents, seven were falls, two children were burnt, one child pulled a fireguard on top of himself, and the remaining child took an adult's medicine. The relative risk of having an accident was 0.3 in the intervention group compared with controls ( $95 \%$ confidence interval 0.08 to 1.14 ).

Children's diet was assessed by the length of time they were kept on formula feeds, the age they started cows' milk, and 24 hour recall by the mother. Mothers kept their children on formula feeds significantly longer in the intervention group than in the control group (38.1 (SD 13.5) weeks $v 28.0(15.2)$ weeks; difference between means $10 \cdot 1$ weeks ( $95 \%$ confidence interval 6.4 to 13.8 weeks); $p<0.001$ ). Twenty four mothers $(19 \%)$ in the intervention group compared with $49(47 \%)$ of the controls $(p<0.0001$; relative risk 0.40 (95\% confidence interval 0.27 to 0.61$)$ ) gave their children cows' milk before 26 weeks. The results of the 24 hour dietary recall are shown for children and their mothers in tables IV and V. For all food groups both children and mothers in the intervention group performed significantly better than the controls.

Of the $182(78 \%)$ mothers who said that they read to their child, significantly more were in the intervention group $(125 ; 98 \%)$ than in the control group $(57 ; 54 \%)$ $(\mathrm{p}<0.0001$; relative risk 1.81 (95\% confidence interval 1.52 to $2 \cdot 16)$ ). Of mothers who read to their child, significantly more in the intervention group $(70 ; 56 \%)$ than in the control group $(15 ; 26 \%)$ did so daily $(\mathrm{p}<0.0001$; relative risk $2.13(95 \%$ confidence interval $1 \cdot 34$ to $3 \cdot 38)$ ).

Table VI outlines the differences between the two groups for developmental stimulation scores and the scores for positive and negative feelings. With the exception of motor games the differences between the two groups were highly significant $(p<0.01)$ in favour of the intervention group.

Because a difference was found between the two groups with respect to mothers' and fathers' employment status employment was treated as a possible confounder. The data were therefore reanalysed. Controlling for employment status, however, had no significant effect on the results.

\section{Discussion}

The child development programme from which the community mothers' programme evolved is a well designed intervention programme whose essential feature is the empowerment of the parent. The parent is regarded on equal terms and not given advice by the community mother. Instead the community mother shares her own experiences with the new mother and raises her self esteem and confidence in herself as a parent. ${ }^{45}$ This philosophy accords with the Alma Ata approach to community based health care $^{6}$ but is rarely seen in a Western European health programme. By using non-professional people to deliver the programme it deviated further from the traditional models and made this approach unique in Western Europe. However, it gave rise to some difficulties in evaluation. Firstly, there was little published work available for comparison and, secondly, there was no established methodology for evaluating such an approach. It was necessary to develop our own approach, relying heavily on previous work related to the child development programme. $^{2}$

A further problem with our study is the lack of blindness of the family development nurses who administered the end of year questionnaire. Unfortunately, resources did not allow for an independent data collector. Though the possibility of bias cannot be ruled out directly, cross checking of mothers' responses on immunisations against other sources of this information did not uncover any discrepancies. We also emphasise that whatever bias that might exist could theoretically operate against the programme, as family development nurses are in effect being replaced by community mothers in carrying out the programme. Despite these difficulties the strength of the association between a favourable result for several outcomes and membership of the intervention group was impressive.

The community mothers' programme failed to show a benefit with respect to hospitalisation whereas the child development programme was associated with a sharp drop in admissions from the intervention group. However, children were admitted for various conditions which were not addressed specifically by the community mothers' programme and which the programme could not be expected to influence to a meaningful degree. Our finding three cases of child abuse among the controls as against none in the intervention group was not significant but was in keeping with the finding in Belfast, where a reduction of about $50 \%$ occurred in the intervention group. 
Thus our results are generally similar to other evaluations of the child development programme.

We know of only one other programme with broadly similar goals-namely, the "head start" programme in the United States.910 However, it is aimed at preschool children and based on a professional model of intervention, so that comparisons would be inappropriate.

These results tend to confirm that the empowerment approach to promoting parenting skills developed by Barker $^{1}$ is sound, practical, and effective. That the programme can be delivered effectively by non-professionals, themselves mothers living in disadvantaged areas, is of great interest. We would, however, like to compare the cost effectiveness of this approach with that of intervention by professional workers.

At the end of 1991 the overall budget for the community mothers' programme was around £Ir 50000 . This included the salaries of 11 family development nurses, a clerical assistant, and $£$ Ir 2 per visit paid to a community mother as well as other non-remunerative items. One hundred and thirty community mothers served throughout 1991, visiting between 900 and 1000 first time parents. Indeed, such has been the success of the programme that other Irish health authorities have expressed an interest in developing similar projects, and discussions are under way.

Possibly community mothers or other non-professional workers might serve in other areas of health promotion also. This and the present issues merit further study.

We thank Eastern Health Board personnel for their help, particularly M Kelly, T Parle, T Keggan, A Savage, C Byrne, and P O'Doherty; Walter Barker, originator of the child development programme; the Department of Social Work, University of Bristol; and the parents and children who form the basis of this report. We are greatly indebted to Barry Merriman for the statistical analysis. This project was supported by the Bernard van Leer Foundation, The Hague.

1 Barker W. The child development programme: a collaborative programme linking parents, community and health visitors. Bristol: Early Childhood Development Unit, University of Bristol, 1984

2 Barker $\mathrm{W}$, Anderson $\mathrm{R}$. The child development programme: an evaluation of process and outcome. Bristol: Early Childhood Development Unit, University of Bristol, 1984.

3 Health Education Bureau. Recommended dietary allowances. Dublin: Department of Health, 1983.

4 Percy P, Barker W. The child development programme. Midwife, Health Visitor and Community Nurse 1986;22:235-40.

5 Barker W. Parent power. Nursing Standard 1990;4:43-4.

6 World Health Organisation. Targets for health for all. Copenhagen: WHO Regional Office for Europe, 1985.

7 Barker W. Child development programme-evaluation document 8. Bristol: Early Childhood Development Unit, University of Bristol, 1987.

8 Barker W, Anderson R, Chalmers C. Early health and development monitorevaluation document 11. Belfast: preliminary findings on the results of the child development programme. Bristol: Childhood Development Unit, University of Bristol, and Eastern Health and Social Services Board, Belfast, 1987.

9 Besharov DJ, Hartle TW. Head start: making a popular programme work. Pediatrics 1987;79:440-1.

10 Kotelchuck M, Richmond JB. Head start: evolution of a successful comprehensive development programme. Pediatrics 1987;79:441-4.

(Accepted 25 March 1993)

\title{
What are the complications of influenza and can they be prevented? Experience from the 1989 epidemic of $\mathrm{H} 3 \mathrm{~N} 2$ influenza $A$ in general practice
}

\author{
Ann Marie Connolly, R L Salmon, B Lervy, D H Williams
}

PHLS Communicable

Disease Surveillance Centre (Welsh Unit), Cardiff CF4 3QX

Ann Marie Connolly, senior registrar in public health medicine

R L Salmon, consultant epidemiologist

Llys Meddyg, The Surgery, Morriston, Swansea

SA6 6HU

B Lervy, general practitioner

Eglwysbach Surgery, Pontypridd, Mid

Glamorgan CF37 2AA

D H Williams, general

practitioner

Correspondence to:

Dr R L Salmon

BMf 1993;306: 1452-4

\section{Abstract}

Objectives-In an epidemic: to measure the incidence and risk of complications of influenza; to determine the effect of pre-existing disease on complications; to estimate vaccine uptake and efficacy.

Design-Case-control study.

Setting-Primary care: two group practices.

Subjects-342 of the 395 cases of clinically diagnosed influenza reported to the general practice surveillance of infectious diseases scheme of the Public Health Laboratory Service during the 1989 epidemic, and 342 age and sex matched controls.

Interventions-Examination of records.

Main outcome measures-Documented recognised complications; hospital admission; previous vaccination.

Results-Of 15 recognised complications, bronchitis was the commonest (rate 190.1/1000 cases) and significantly commoner in cases (summary odds ratio 9.7 ) after adjusting for higher consultation rates (mean 6.1 per annum $v 4.2$ among controls; $p<0.0001)$. No deaths were recorded. The risk of bronchitis complicating influenza was higher in patients with pre-existing illnesses regarded as an indication for vaccination (odds ratio 3.3; $p<0.0001$ ). Observed vaccination efficacy in those with pre-existing illnesses and in elderly subjects was high (63\% and $77 \%$ respectively) but uptake was low (4.5\% and $6 \cdot 1 \%$ respectively).

Conclusions-Bronchitis complicates about one fifth of all cases of influenza presenting to general practitioners. Patients with pre-existing illnesses regarded as an indication for vaccination are particu- larly at risk. Vaccine uptake is extremely low, precluding an unequivocal demonstration of a protective effect.

\section{Introduction}

Influenza is the most important viral infection of the respiratory tract, ${ }^{12}$ partly because of the scale of epidemics and partly because of complications, which include excess mortality, ${ }^{3}$ several medical conditions, ${ }^{4}$ ${ }^{8}$ and exacerbations of pre-existing diseases. ${ }^{9}$ However, little is known about the expected incidence of these complications. Knowledge tends to be based on complications observed in hospital. Of 237 English language reports since 1966 on influenza and complications cited in Medline, none measure the incidence of complications in the community.

In 1989 there was the first epidemic of influenza $A$ in the United Kingdom since $1975 .{ }^{10}$ We studied the epidemic in Wales in order $(a)$ to measure the incidence and risk of complications, $(b)$ to identify the rate of hospitalisation, (c) to determine the effect of preexisting disease on the development of complications, and $(d)$ to estimate vaccine uptake and efficacy.

\section{Subjects and methods}

Influenza in Wales is monitored as part of the general practice surveillance of infectious diseases scheme of the Public Health Laboratory Service Communicable Disease Surveillance Centre (Welsh Unit). " This scheme comprises 34 spotter practices that provide weekly returns of cases of eight infectious diseases seen 